
\title{
3 Research Square \\ Breastfeeding Knowledge, Attitude, and Practice among White-Collar and Blue-Collar Workers in Indonesia
}

\section{Ray Wagiu Basrowi}

Universitas Indonesia

Astrid W Sulistomo

Universitas Indonesia

Nuri Purwito Adi

Universitas Indonesia

Indah S Widyahening

Universitas Indonesia

Yvan Vandenplas ( $\nabla$ yvan.vandenplas@uzbrussel.be )

Universitair Ziekenhuis Brussel https://orcid.org/0000-0002-1862-8651

Research article

Keywords: breastfeeding; blue-collar worker; white-collar worker; lactation practice; workplace

Posted Date: August 11th, 2019

DOI: https://doi.org/10.21203/rs.2.12585/v1

License: (9) This work is licensed under a Creative Commons Attribution 4.0 International License. Read Full License

Version of Record: A version of this preprint was published at Journal of Korean Medical Science on January 1st, 2019. See the published version at https://doi.org/10.3346/jkms.2019.34.e284. 


\section{Abstract}

Objective Working status is identified as a major risk factor of poor breastfeeding practices among workers. This study aimed to evaluate the knowledge, attitude, and factors associated to breastfeeding practice among white-collar and blue-collar workers in Indonesia. Methods A cross-sectional study was performed in two factories and three government offices in Jakarta from December 2012 to February 2013. Subjects were female workers whose children aged 6 months to 24 years old and actively working in the factory and/or office. The factors studied were selected socio-demographic and occupational characteristics, score on knowledge and attitude and breastfeeding practice during working hours. Results From a total of 192 subjects, $73 \%$ of white-collar workers had good knowledge on breastfeeding, in contrast with $55 \%$ of blue-collar workers who had not good of breastfeeding knowledge $(P<0.001)$. Most of the subjects were conducting breast pumping during working hours, however $15 \%$ of white-collar worker and $17 \%$ of blue-collar worker were never breastfeed nor breast pumping at work. Working status $(P=0.005)$ and knowledge $(P=0.002)$ were factors associated with breastfeeding practice among workers. Conclusion White-collar workers have a better knowledge, attitude, and practice toward breastfeeding. Knowledge improvement related to breastfeeding benefits and supports to working mothers are key priority, however advocacy to employers, manager, and supervisor in providing breastfeeding facilitations and programs support were also critical to successful breastfeeding practice among workers.

\section{Introduction}

Working status has been identified as a major risk factor of breastfeeding discontinuation and poor lactation practices among workers. Specific interventions to improve education and knowledge of health and lactation in a working mother population helps to improve the health behavior and attitude. A study in Jordanian women showed that better level of knowledge, education and lactation promotion support at the workplace helps to improve the breastfeeding practices among workers. ${ }^{1}$ Several studies also found some socio-demographic variables, including education level and knowledge, strongly related to the practice of health behaviors, including lactation practice. ${ }^{2-4}$ Similar evidence from Duffy reported that age and education affected healthy life style behaviors among workers. ${ }^{5}$

Unfortunately, a study in Indonesia showed that only $21.5 \%$ of workers have access to proper lactation support at work and only $7.5 \%$ of workers benefits from adequate lactation education support/program provided by the employers, which was indicated the poor support of knowledge improvement initiatives in workers. ${ }^{6}$ Hence, the prevalence of exclusive breastfeeding among blue-collar worker (manufacture labor) in Indonesia is only $19 \%$, far below national prevalence which was $38 \%{ }^{7}$

Workers were defined as white-collar workers by the following 14 job titles: administration, management, accounting, business, planning, personnel affairs, human resources, marketing, distribution, inspection, customer service, sales, supporting and international sales. Blue-collar workers were defined as those with other than a white-collar job title. ${ }^{8}$ A study in Makassar, Indonesia reported that due to lower 
educational background, blue-collar workers tend to show a lack of knowledge and have improper health behavior at work. ${ }^{9}$

This study aimed to evaluate the knowledge, attitude, and breastfeeding practice among white-collar and blue-collar workers in Indonesia and to identify factors associated with breastfeeding practice during working hours.

\section{Material/subjects/patients And Methods}

A cross-sectional study was performed in two factories and three government offices in Jakarta, Indonesia from December 2015 to February 2016. Sample size was calculated using single proportion sample formula for a descriptive study that indicated a minimum of 160 subjects required. Inclusion criteria were female workers whose children were between 6 and 36 months old, actively working in the particular factory or office at the last 12 months and agreed to participate in the study by signing the informed consent. The study protocol was approved by the Ethics Committee Faculty of Medicine Universitas Indonesia letter number 668/PT02.FK/ETIK/2012.

\section{Data collection and statistical analysis}

A set of self-administered questionnaires was distributed to obtain data related to demographic, occupational, knowledge, attitude and lactating practices in workplace. The questionnaire was modified from Basrowi et al. study [6], after being consulted with experts from Division of Occupational Medicine Faculty of Medicine Universitas Indonesia, with reliability test Cronbach's Alpha 0.706.

Knowledge on breastfeeding was measured using 11 items of multiple-choice questions format, related to subject's understanding of definition, perception, and benefits of exclusive breastfeeding to the infants and mothers based on World Health Organization standard, as well as the understanding on government regulation and company's policy related to lactation support and program in workplace. Attitude was determined by series of multiple-choice questions and a true/false format, indicating the subject's support, feelings, and responses toward breastfeeding in workplace, including questions on supervisors and peers influences and supports received by subject when they were breastfeeding or breast-pumping during working hours. Knowledge and attitude score indicated by 'good' if total score was $>80$ and 'not good' if score was $<80$.

Lactation practice was defined as a breastfeeding behavior of subject in the workplace during working hours, indicated as a 'breastfeeding only' if the subject only directly breastfed the infant at the workplace or went home to breastfeeding; 'breast pumping only' indicated if the subjects only fed expressed breastmilk in any location in the workplace during working hours; 'mixed breastfeeding and breast pumping' indicated if the subject combined the lactating practice by breastfeeding the infant directly and also gave expressed breastmilk during working hours; 'never breastfeed' indicated if subject never breastfeeding nor gave expressed breastmilk during working hours. The location of breastfeeding and/or breast pumping was also identified. 
A chi-square test was performed to analyse cross-tabulated data for bivariate analysis between knowledge, attitude, breastfeeding practice and occupation (white-collar and blue-collar worker). A logistic regression model was performed for multivariate analysis of demographic, occupational and outcomes variables related to breastfeeding practice. The statistical analyses were performed using SPSS version 20 . $P$ values $<0.05$ were considered to be statistically significant.

\section{Results}

A total of 192 female workers participated in this study with age ranged from 20 to 45 years (mean $31.88+4.39$ years) (data shown in in Table 1 ).

\section{Breastfeeding knowledge and attitude}

Majority (72\%) of blue-collar workers had a lack of knowledge regarding breastfeeding definition, benefits and awareness of policy and regulation of breastfeeding at the workplace, hence indicating as a 'not good' of breastfeeding knowledge (Table 2). On the contrary, white-collar workers showed a significantly higher percentage of good knowledge about breastfeeding (55\%). However, the level of knowledge in both groups of workers does not reflect the breastfeeding attitude in the workplace. The percentage of whitecollar workers that had a good breastfeeding attitude was significantly higher than the blue-collar workers, $72 \%$ versus $57 \%$ respectively $(P=0.045)$.

\section{Breastfeeding practice}

When the subjects were asked about their lactation practice during working hours, a higher percentage of subjects ( $72 \%$ white-collar and $65 \%$ blue-collar) mentioned that they were only breast pumping in the office/factory, while only $9 \%$ of the white-collar workers and $15 \%$ of the blue-collar workers directly breastfed their infants during working hours by bringing them to the office/factory during lunch-break 0 went back home if they lived nearby the workplace, although the result were not statistically significant. Nevertheless, more than $10 \%$ of subjects in both groups ( $15 \%$ of white-collar and $17 \%$ of blue-collar) mentioned that they never breastfed nor pumped breastmilk during working hours.

Table 3 shows that workers who never breastfed or pumped milk at the workplace felt uncomfortable and worried about leaving the job to feed the baby or express milk (44\%). Other reasons reported were: inaccessible and inconvenient lactation room in the office/factory (19\%), inadequate volume of breastmilk (10\%) and not permitted to breastfeeding/ breast-pumping by their supervisor (6\%).

The subjects were also asked about the location where they could breastfeed/breast pumping at workplace: $50 \%$ mentioned that they were expressing milk in the toilet or bathroom and only $16 \%$ were using the lactation room provided in the office/factory. White-collar workers with a higher level of position, reported to breast pump in their own cubicle as this is much more convenient. 
We performed a multivariate analysis to identify variables associated with subject's breastfeeding or lactation practice in workplace. Table 4 shows that working as a full-timer $(P=0.005)$ and good knowledge $(P=0.002)$ were strongly correlated with the lactation behavior and practice among workers.

\section{Discussion}

\section{Relationship between breastfeeding knowledge and attitude among workers}

Our study showed that white-collar workers have a higher percentage of adequate/good knowledge about breastfeeding compared to blue-collar workers, and hence had higher percentage of 'good attitude' towards breastfeeding. This might be related to the higher education level of white-collar workers. Pender et al. found that white-collar workers enrolled in workplace promotion programs were more likely to report a healthy lifestyle. ${ }^{10}$ Galtry et al. found that being blue collar or lower income generally implies lower skill requirements, less flexibility and even less protective working rights hence affecting the health behavior. ${ }^{11}$

Particularly for the breastfeeding attitude, a study from Malaysia reported that there was a strong correlation between higher education and better knowledge of breastfeeding with the positive attitude and behavior of breastfeeding among women workers. ${ }^{12}$ According to this study, the greatest incremental of breast feeding and lactating practice occurred among women with at least some secondary education. Ciftci et al. also mentioned that there is a positive effect of women who have an increased awareness and knowledge of the benefits of breastmilk, resulting in a higher frequency of breastfeeding. ${ }^{13}$ Data from Indonesia confirmed these findings. ${ }^{14}$

The relationship between knowledge and attitude towards breastfeeding are also reported in studies from Ethiopia, ${ }^{15} \mathrm{Nepal}^{16}{ }^{16}$ Tunisia $^{17}$ and Tanzania ${ }^{18}$, all indicating that mothers who have an adequate knowledge about breastfeeding have a higher likelihood or probability for exclusive breastfeeding.

However, this study also found that despite the high percentage of inadequate knowledge about breastfeeding among blue-collar workers, this group still had a high percentage of positive attitude towards breastfeeding. A study in Taiwan reported that intention or knowledge alone is not sufficient to overcome barriers to breastfeed. ${ }^{19} \mathrm{~A}$ study in Nigeria founded that there was an average decrease in breast feeding duration of 3.2 and 6.6 months correlating with mother's education to primary and secondary levels, respectively, compared to mothers with no education. ${ }^{20}$ This finding is similar with the finding of our study that the level of education and knowledge will not necessarily determine the attitude of working women to breastfeed or breast pumping in the workplace.

There were numerous influencing factors including the support of adequate lactation facilities and programs at workplace that potentially improve lactation practices among female workers. Several studies in Indonesia have suggested that apart of knowledge capacity building, a lactation counselor at work, lactation facilities, and support by peers would be critical and hence could help working mothers continue breastfeeding and have a positive breastfeeding attitude. ${ }^{21-23}$ Family support also plays an 
important role. ${ }^{6}$ These factors are key to potentially help mothers to have positive attitude of breastfeeding despite the lower and inadequacy knowledge of breastfeeding.

\section{Work-related determinants toward breastfeeding practice among workers}

Another important finding of our study is the lactation or breastfeeding practice, the reasons to not breastfeed and the location of breastfeed in workplace. In this study, there were $15 \%$ of white-collar workers and $17 \%$ of blue-collar workers were never breastfeed during working hours, for three main reasons; i.e. feel hesitant to take a break during work, an uncomfortable lactation room and not allowed by the supervisors. Studies showed that a dual role of being a lactating mother and an employee at the very same time put them in a difficult situation and brings potential conflict in their daily life ${ }^{24}$ In many situations, an employed mother tends to sacrifice the lactation/breastfeeding role in order to pursue career or to meet the job's target. This is definitely an unfortunate situation for working mothers with infants, since it will affect the health of both mothers and infants.

Although the Indonesian government had issued a series of breastfeeding protection policies at the workplace, such as the Joint Regulation on Promoting and Protecting Breastfeeding at Workplace year 2008 and the Ministry of Health Regulation Number 15/2013 with a technical guideline for a dedicated lactation room and facilities at the workplace, only $21.5 \%$ of the female workers had access to adequate lactation facilities in the workplace and only $7.5 \%$ of the workers benefitted of breastfeeding promotion

support during working hours. ${ }^{6} \mathrm{~A}$ study from the USA reports that only $3 \%$ of the companies have written policies on breastfeeding at work, even though the majority of companies allow women to express breast milk at the workplace. Only $22 \%$ of the companies allowed breastfeeding in the company premises and only $32 \%$ provided a designated room solely for breastfeeding or breast pumping. ${ }^{25}$ Chun Yi et al in Taiwan also found that even if the employer provided a lactation room and allowed an hour break for breast milk pumping, workers found it difficult; and it also could take up to 10-15 minutes to travel between the worksite and the lactation room. ${ }^{19}$ This might explain the finding of our study why there is still a large number of workers that decided to not breastfeed during working hours and that $50 \%$ of the workers decided to pump at the toilet or bathroom instead of the lactation room.

\section{Employers and supervisor's perception toward breastfeeding practice at workplace}

The perception of workers, managers/supervisors and employers towards productivity is another aspect. In our study, $42 \%$ of the workers who decided to not breastfeed or pump during working hours mentioned that they felt hesitant to leave their work and $6 \%$ of the workers were not allowed by their supervisors. Tsai found that $51.1 \%$ of female workers assumed that taking a break for breast pumping two times during working hours could lower their work productivity. ${ }^{26}$

From the employer point of view, managers and employers consider that breast pumping during working hours might hamper productivity and affect working performance. A survey found that most employers would be willing to institute breastfeeding support at work, although they saw no benefit to support 
breastfeeding. ${ }^{27}$ Blue collar workers have their own difficult circumstances in participating in worksite health promotion programs due to the lack of social support by the supervisor. In order to keep the production lines moving, supervisors may refuse to allow workers to attend programs during company time. ${ }^{28}$ Group leader and the manufacturer's performance bonus systems may reduce the willingness of women to breastfeed at the workplace. If a group leader disagrees with breastfeeding but the worker continues to breast pump during work hours, it will affect her work performance and bonus. ${ }^{19}$ Overall, employers do not prioritize providing breastfeeding support at the workplace. ${ }^{29}$

Based on multivariate analysis, our study found that the working status and level of knowledge are key variables determining the subject's lactation practice. This was reported in the systematic review by Dinour et al., suggesting that providing a lactation space was the most common employer-based support accommodation studied, followed by breastfeeding breaks and comprehensive lactation support programs targeting the knowledge improvement of lactating workers. ${ }^{30}$ Mothers report multiple barriers to breastfeeding upon return to work, such as work schedule flexibility and program support in workplace. $^{31}$

Involvement of a policy maker in the company and a regular promotion program aimed to improve education and breastfeeding knowledge among women worker were put in place to increase lactation practice. ${ }^{32} \mathrm{~A}$ workplace-based lactation promotion model, i.e. policy and regulation, facility, education, and human resources are key components to achieve successful breastfeeding and lactation in the workplace. $^{33}$

\section{Study strengths and limitations}

The findings related to the profile of breastfeeding knowledge and attitude between white-collar and bluecollar workers in Indonesia are considered as the strength of this study, as to our knowledge such data had never been reported. The reasons and preferred location of lactation during working hours were also a novel finding and provides significant insight for future improvement of breastfeeding policy. However, designed as a cross-sectional study with self-administered questionnaire, without factor analysis, brings a major limitation of this study outcome, since the subjectivity of the responses cannot be excluded.

\section{Conclusion}

Knowledge improvement related to breastfeeding benefits and supports to working mothers are key priority as it is strongly correlated to the breastfeeding attitude and practice in the workplace. The bluecollar workers would need more attention in such of supports as the complexity of job and education and/or knowledge level are factors associated with inadequate breastfeeding attitude and practice. However, advocacy about the role and understanding of employers, manager, and supervisor in providing breastfeeding facilitations and programs support were also critical, not only because it is mandated by government regulation but it is also important to the health of workers. 


\section{Declarations}

Acknowledgement: We are thankful to the support of Ibu Anindiarti in field operation and data collection of this study.

Conflict of interest: RWB is employee of Nestle Nutrition Institute. YV has participated as a clinical investigator, and/or advisory board member, and/or consultant, and/or speaker for Abbott Nutrition, Danone, Nestle Health Science, Nestle Nutrition Institute, Nutricia, Mead Johnson Nutrition, United Pharmaceuticals, Wyeth. Other authors declared no conflict of interest.

Funding disclosure: This study received no external funding.

\section{References}

1. Al-Maaitah R, Haddad. Health promotion behaviors of Jordanian women. Health Care for Women International. 1999;20:533-47.

2. Ahijevych K, Bernhard L. Health promoting behaviors of African-American women. Nursing Res. 1994;42:86-9.

3. Bahar S, Beser A, Ozbicakci S, Haney MO. Health promotion behaviors of Turkish women. Health Promotion and Women. 2013;6:9-16.

4. Resnick B. Health promotion practices of older adults: model testing. Public Health Nursing. 2003;20:2-12.

5. Duffy E, Rossow R, Hernandez M. Correlates of health promotion activities in employed MexicanAmerican women. Nursing Res. 1996;45:18-24.

6. Basrowi RW, Sulistomo AW, Adi NP, Vandenplas Y. Benefits of a dedicated breastfeeding facility and support program for exclusive breastfeeding among workers in Indonesia. Pediatr Gastroenterol Hepatol Nutr. 2015;18:94-99.

7. Ministry of Health Republic of Indonesia. Basic health survey. Riskesdas Kemenkes RI. 2018.

8. Korea Ministry of Labor. Enforcement regulations for industrial safety and health act. Seoul: Korea Ministry of Labor. 2003.

9. Mallapiang F, Damayati DS, Fadillah N. Gambaran perilau tenaga kerja dan pelaksanaan program kesehatan dan keselamatan kerja (K3) konstruksi dalam pembangunan balai diklat BPK-RI Makassar oleh PT. Wijaya Karya (Persero) tbk. Public Health Science Journal. Undergraduate S1 thesis. UIN Allaudin, Makassar, February 4, 2016.

10. Pender NJ, Walker SN, Sechrist KR, Frank-Stromborg M. Predicting health-promotion lifestyles in the workplace. Nursing Research. 1990; 39:326-331.

11. Galtry J. Extending the 'bright-line': feminism, breastfeed and the workplace in the United States. Gender \& Society. 2000;14:295-317. \ 
12. DaVanzo J, Sine J, Peterson C, Haaga J. Reversal of the decline in breastfeeding in Peninsular Malaysia Ethnic and educational differentials and data quality issues. Soc Biol. 1994;41:61-77.

13. Çiftçi EK, Arikan D. The effect of training administered to working mothers on maternal anxiety levels and breastfeeding habits. J Clin Nurs. 2012;21:2170-2178.

14. Susiloretni KA, Hadi H, Prabandari YS, Soenarto YS, Wilopo SA. What works to improve duration of exclusive breastfeeding: lessons from the exclusive breastfeeding promotion program in rural Indonesia. Matern Child Health J. 2014;19:1515-1525. \&

15. Seid AM, Yesuf ME, Koye DN. Prevalence of exclusive breastfeeding practices and associated factors among $\llbracket$ mothers in Bahir Dar city, Northwest Ethiopia: a community based cross-sectional study. Int Breastfeed J. 2013;8:14.

16. Ulak M, Chandyo RK, Mellander L, Shrestha PS, Strand TA. Infant feeding practices in Bhaktapur, Nepal: a cross-sectional, health facility-based survey. Int Breastfeed J. 2012;7:1. \

17. Bouanene I, El Mhamdi S, Sriha A, Bouslah A, Soltani M. Knowledge and practices of women in Monastir, Tunisia regarding breastfeeding. East Mediterr Health J. 2010;16:879-85.

18. Nkala TE, Msuya SE. Prevalence and predictors of exclusive breastfeeding among women in Kigoma

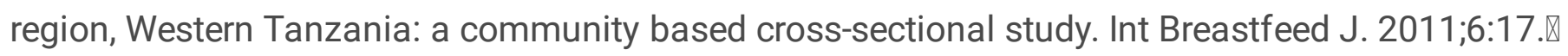

19. Chen YC, Wu YC, Chie WC. Effects of work-related factors on the breastfeeding behavior of working mothers in a Taiwanese semiconductor manufacturer: a cross-sectional survey. Nutr Health. 1996;11:115-26.

20. Davies-Adetugbo AA, Ojofeitimi EO. Maternal education, breastfeeding behaviors and lactational amenorrhoea: studies among two ethnic communities in lle Ife, Nigeria. Nutr Health. 1996;11:115126.

21. Abdullah GI, Ayubi D. Determinan perilaku pemberian air susu eksklusif pada ibu pekerja. J Kesmas. 2013;7:298-303. 区

22. Wulandari E. Pengaruh pendidikan laktasi di tempat 『kerja terhadap self-efficacy pemberian ASI eksklusif pada pekerja wanita usia subur: Studi kasus di Chevron IndoAsia Business unit Jakarta. Thesis. Universitas Indonesia. 2010.

23. Rejeki S. Pengalaman menyusui ibu bekerja di daerah Kendal Jawa Tengah. Thesis. Universitas Indonesia. 2004. 『

24. Oktariyanti F. Manajemen konflik pada perempuan dengan peran ganda; Studi pada ibu bekerja di kota Malang. Thesis. Universitas Brawijaya. 2012.

25. Hojnacki SE, Bolton T, Fulmer IS, Olson BH. Development and piloting of an instrument that measures company support for breastfeeding. J Hum Lact. 2012;28:20-7.

26. Tsai SY. Influence of partner support on an employed mother's intention to breastfeed after returning to work. Breastfeed Med. 2014;9:222-230. 『

27. Libbus MK, Bullock LF. Breastfeeding and employment: an assessment of employer attitudes. Journal of Human Lactation. 2002;18:247-251. 区 
28. Sorensen G, Barbeau E, Hunt MK, Emmons K. Reducing social disparities in tobacco use: a socialcontextual model for reducing tobacco use among blue-collar workers. Am J Public Health. 2004;94:230-239. 区

29. Brown CA, Poag S, Kasprzycki C. Exploring large employers' and small employers' knowledge, attitudes, and practices on breastfeeding support in the workplace. Journal of Human Lactation. 2001;17:39-46.

30. Dinour LM, Szaro JM. Employer-based programs to support breastfeeding among working mothers: A systematic review. Breastfeed Med. 2017;12:131-141.

31. Haviland B, James K, Killman M, Trbovich K. Policy Brief: supporting breastfeeding in the workplace. [accessed on 11 November 2018], Available online: http://www.asphn.org/resource_files/657/657_resource_file2.pdf.

32. Basrowi RW, Sastroasmoro S, Sulistomo AW, Bardosono S, Hendarto A, Soemarko DS, Sungkar A, Khoe LC, Vandenplas Y. Challenges and supports of breastfeeding at workplace in Indonesia. Pediatr Gastroenterol Hepatol Nutr. 2018;21:248-256

33. Basrowi RW, Sastroasmoro S, Sulistomo AW, Bardosono S, Hendarto A, Soemarko DS, Sungkar A, Khoe LC, Vandenplas Y. Developing a workplace lactation promotion model in Indonesia using Delphi technique. Arch Public Health. 2018;76:70.

\section{Tables}

Table 1: Demographic and Occupational Characteristic of the Workers 


\begin{tabular}{lll} 
Characteristic & $\mathbf{N}$ & $\%$ \\
& $\mathbf{n}=192$ & \\
\hline Education & & \\
\hline Junior High School or below & 46 & 24 \\
\hline Senior High School & 74 & 38.5 \\
\hline University/academy & 24 & 12.5 \\
\hline Occupation & & \\
\hline White-collar (Office worker) & 68 & 35.4 \\
\hline Blue-collar (Labor/factory worker) & 124 & 64.6 \\
\hline Employment status & & \\
\hline Permanent and full-time & 185 & 96.4 \\
\hline Part-timer & 7 & 3.6 \\
\hline Length of work & & \\
\hline$\leq 1.5$ years & 90 & 46.9 \\
\hline$>1.5$ years & 102 & 53.1 \\
\hline Monthly salary (IDR) & & \\
\hline $750,000-1,500,000$ & 74 & 38.5 \\
\hline $1,500,000-3,000,000$ & 55 & 28.6 \\
\hline $3,000,000-9,000,000$ & 32 & 16.7 \\
\hline$>9,000,000$ & & 16.2 \\
\hline
\end{tabular}

1 USD = 14,000 IDR (data on national currency exchange 2019

Table 2: Knowledge, Attitude and Breastfeeding Practice based on Subject's Occupation 
Variables

\section{White-collar \\ worker}

$\mathrm{n}=68$

N

38

Blue-collar worker

OR

p

(95\% Cl)

\begin{tabular}{|c|c|c|c|c|c|c|}
\hline & $\mathrm{N}$ & $\%$ & $\mathrm{n}$ & $\%$ & & \\
\hline \multicolumn{7}{|l|}{ Knowledge } \\
\hline Good & 38 & 55 & 34 & 27 & $\begin{array}{l}3.35 \\
(1.80- \\
6.24)\end{array}$ & $\dot{0.001}$ \\
\hline Not good & 30 & 45 & 90 & 73 & & \\
\hline \multicolumn{7}{|l|}{ Attitude } \\
\hline Good & 49 & 72 & 71 & 57 & $\begin{array}{l}1.92 \\
(1.02- \\
3.64)\end{array}$ & 0.045 \\
\hline Not good & 19 & 28 & 53 & 43 & & \\
\hline \multicolumn{7}{|l|}{ Breastfeeding Practice } \\
\hline Breastfeeding only & 6 & 9 & 18 & 15 & & 0.589 \\
\hline Breast-pumping only & 49 & 72 & 80 & 65 & & \\
\hline $\begin{array}{l}\text { Combined breastfeeding and } \\
\text { breast-pumping }\end{array}$ & 3 & 4 & 4 & 3 & & \\
\hline Never breastfeeding & 10 & 15 & 22 & 17 & & \\
\hline
\end{tabular}

$P$ value: knowledge and attitude using Fisher's Exact Test; Breastfeeding practice using Pearson Chisquare

Table 3. Reasons of Workers Never Breastfeeding or Breast-pumping in Workplace 


\begin{tabular}{lll} 
Reasons & $\mathbf{n}$ & \% \\
& $(\mathbf{n}=\mathbf{3 2 )}$ & \\
\hline Worried of leaving the job during working hours & 14 & 44 \\
\hline Inadequate volume of breastmilk & 3 & 10 \\
\hline Uncomfortable to breast-pumping at work & 1 & 3 \\
\hline Lactation room location was too far & 2 & 6 \\
\hline Lactation room was always full and inconvenient & 6 & 19 \\
\hline Not permitted by the supervisor & 2 & 6 \\
\hline Breast pump before going to work & 1 & 3 \\
\hline Tired & 1 & 3 \\
\hline Busy & 1 & 3 \\
\hline Other & 1 & 3
\end{tabular}

Table 4. Multivariate analysis of Factors Associated with Subject's Lactation Practice in Workplace

\begin{tabular}{lll} 
Variables & OR & P \\
& $(95 \%$ Cl) & \\
\hline Occupation (white-collar) & $0.68(0.28-1.69)$ & 0.412 \\
\hline Working status (full-time employee) & $0.02(0.01-0.30)$ & 0.005 \\
\hline Length of work (>1.5 years) & $0.77(0.32-1.87)$ & 0.564 \\
\hline Knowledge (good knowledge) & $11.83(2.56-54.61)$ & 0.002 \\
\hline Attitude (good attitude) & $0.98(0.41-2.31)$ & 0.957
\end{tabular}

$P$ value: logistic regression 